\section{PRODUCTION \\ ENGINEERING \\ ARCHIVES \\ 2014, Vol. 5, No 4, pp 2-5 \\ ISSN 2353-5156 \\ ISSN 2353-7779 \\ (print version) \\ (online version)}

\title{
Quality education enhancement by means of university environmental edification
}

\author{
Katarína Čekanová ${ }^{1}$, Alena Pauliková ${ }^{2}$ \\ ${ }^{1}$ Slovak University of Technology in Bratislava, Faculty of Materials Science and Technology in Trnava, Institute of safety, environment and \\ quality, Botanická 49, 91724 Trnava, Slovakia, phone: 00421/0908646519, e-mail: katarina.cekanova@ stuba.sk \\ ${ }^{2}$ Slovak University of Technology in Bratislava, Faculty of Materials Science and Technology in Trnava, Institute of safety, environment and \\ quality, Botanická 49, 91724 Trnava, Slovakia, phone: 00421/0908646519, e-mail: alena.paulikova@stuba.sk,
}

\begin{abstract}
The submitted work partly describes the historical and actual trends of the introduction of targeted environmental edification at universities based on the framework of Slovakian sustainable development as well as its enhancement of quality educational processes. There has been a need to accentuate environmental consciousness and to bring closer a current state in an incorporating of more environmental and quality aspects for the education process at technical universities. The article emphasizes continuous development of observed problems and introduces the possible future visions from the point of reorganization and tending of study fields. This reorganization requires very a sensitive approach because duplications or triplicities can frequently occur in the environmental education of individual subjects. For this reason students' interest and ability to learn better can gradually decrease and consequently, results can become worse. Upon graduation, students may not be as well prepared to face the strong competition of the labour market in the Slovak Republic as well as in European Union countries.
\end{abstract}

Key words - environmental edification, quality education, sustainable development, environmental dynamics

\section{Introduction}

The Czechoslovak republic was a country with a relatively high production concentration. Heavy industries and semi-product production were concentrated predominately in the area whereas the consumer industry was in Bohemia. Industrial manufacturing development, which represented the wide range of vehicle production as well as constantly threatening the risk of ecological crisis situations, was required to deal with the restriction of influences for technologies and processes in the environment. However, this was not done in the past and that few or no environmental consciousness was ,underwritten” below environmental debts of our society.

\section{History of Slovak environmental pro- tection and generation}

Several Czech and Slovak ecologists and environmentalists were identified with this opinion. One of the principal authors who considers "ecology" as a science discipline, was A. Dichtl (Animal Ecology, Brno, 1924).

Furthermore, the importance of environmental protection was also emphasized in the works A. Zlatník 
(Fundamentals of Ecology, Prague, 1973) and P. Farb (Ecology, Prague, 1977). Besides conception "ecology" as well as the terms "life environs" and "environment" have begun to be applied.

From Slovak authors who adopted just this terminology, it is necessary to refer to the work of E. Mazúr and J. Hušták (Making More Effective A Science Application - Integrated between Science Solution of Problems With Environment, 1978). In general Slovak authors E. Mazúr J. Drdoš J. Urbánek (Landscape Synthesis and Their Role For Creation of 3D Environmental Structures, 1980) dealt with landscape ecology.

In Slovakia M. LISICKÝ founded nature protection in the framework of ecological base. Considering all of that, the works expressed one common idea. They highlighted a need for being environmentally conscious, in which one is motivated to behave with consideration to the environment (KLINDA J. 1995).

Environmentally developed countries' pressure was a stimulator of new approaches to the environmental development and protection.

\section{Legislative support}

The necessity for integrating the approach was a support and an international unification of legislation. In the Czechoslovak Socialist Republic there existed over 350 juridical standards concerning the partial questions of environmental conservation. For the first time the terms "ecology" and "ecological edification" were put into practice by means of Conception of State Development Of Nature Protection in the SSR (the Slovak Socialist Republic), adopted with the resolution of previous government No. 113/1987 (KLINDA J. 1995).

On $14^{\text {th }}$ June 1991 , during the negotiations of the previous Slovak Commission for Environment the term "environment" was introduced for the first time. The main point of environmental legislative development was to achieve the independency of the Slovak Republic in 1993. The next very important year is 2004, when the Slovak Republic entered the European Union and it was the beginning of an extensive rebuilding of regulations as a consequence of approxi- mation to the laws and edicts towards European legislation.

In Fig. 1 the legislative development of laws is schematically illustrated, public notices and rules concerning environmental edification and education in the framework of environmental legislation.

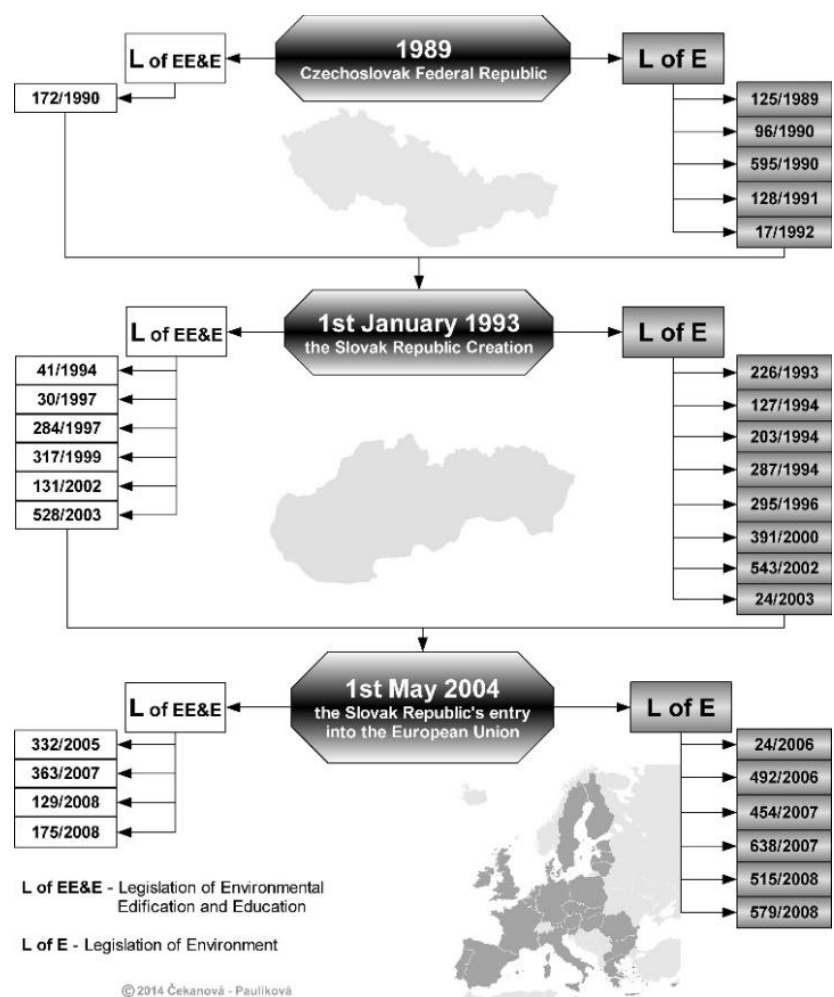

Fig. 1. Development of environmental legislation from point of edification and education in Slovakia.

Source: own study

The environmental care, which is undertaken with the national institutions and represented with environmental policy and legislative standards, would not satisfy an expected aim. It was necessary to transform specified standards together with actual environmental knowledge into not only citizens' minds but also into managers' minds in all regions and all sectors of economic activities.

The first "environmental" points came into existence at the sections of BOZP (Safety and Protection of Health at Work). In firms there were safety technicians often substituted; eventually they were at work in cumulative positions as "environmental conservators". There was a need for environmentally educated people, who would take the new places of "company ecologist" in the system of industrial, manufacturing and 
assembled operations and services. In general environmental activities are conditions of environmental consciousness. This means that the change from consciousness toward behaviour is often a long process (PIATRIK M. 2005)

\section{Environmental edification and educa- tion at Slovak technical universities}

Environmental consciousness itself is received mainly from environmental edification and education in a family as well as through the educational system from nursery right through to university. According to this idea, it is necessary to coordinate edification and education in such a way that people not only understood environmental problems but were also able to solve them from the point of causes and consequences. It is also very important to understand where their place is in this process. However, academic education was under intense pressure because universities were cradles of environmental edification only later. This new system was transferred to lower levels of education. At primary and secondary schools environmental edification was integrated into the curriculum in lowcoordinated way. Up until this time environmental studies had been understood to be like a broad issue rather than an intersection of ecology, biology, geography and chemistry. In the curriculum environmental studies were only small parts of the main study subjects (CHOVANCOVÁ J. 2013).

Since 2000 at universities the coordinated integration of environmental aspects for edification and education at universities is already evident and intercepted in the new environmental curriculum even with technical study fields. The specialised places with environmental orientation - departments as well as faculties have come into existence. They were developing and reorganizing during previous years (PALFY P. 2013).

The actual allocation of Slovak universities, which provide environmental education and edification, is illustrated with a survey map in Fig.2. In the framework of the Slovak republic the allocation of environmental departments and faculties is balanced. The representation of schools with a technical orientation is a most significant fact (FABIAN M. 2013; KOPAS M. 2013).

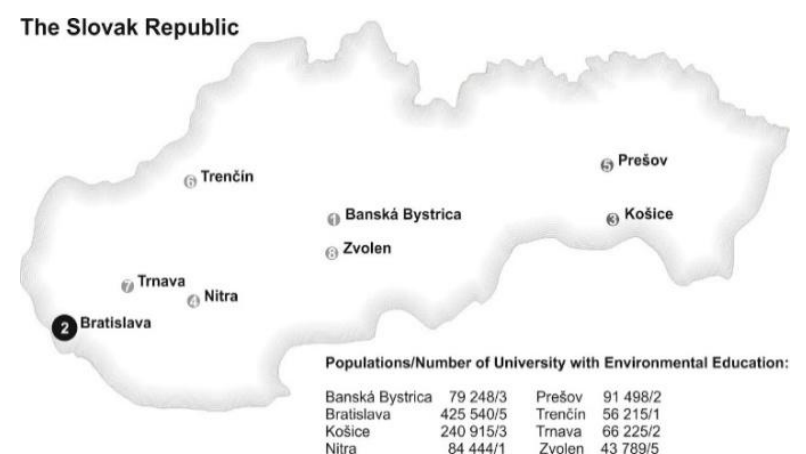

Fig. 2 The allocation of universities providing specialized environmental edification and education.

Source: own study

\section{The new study programme - envi- ronmental dynamics}

Environmental Dynamics (ED) as a new study programme is a fresh challenge for environmental education. The programme would be focused on processes by means of long-term and short-term aspects and would develop present study fields in the abovementioned department. This vision is also included in Fig. 3.

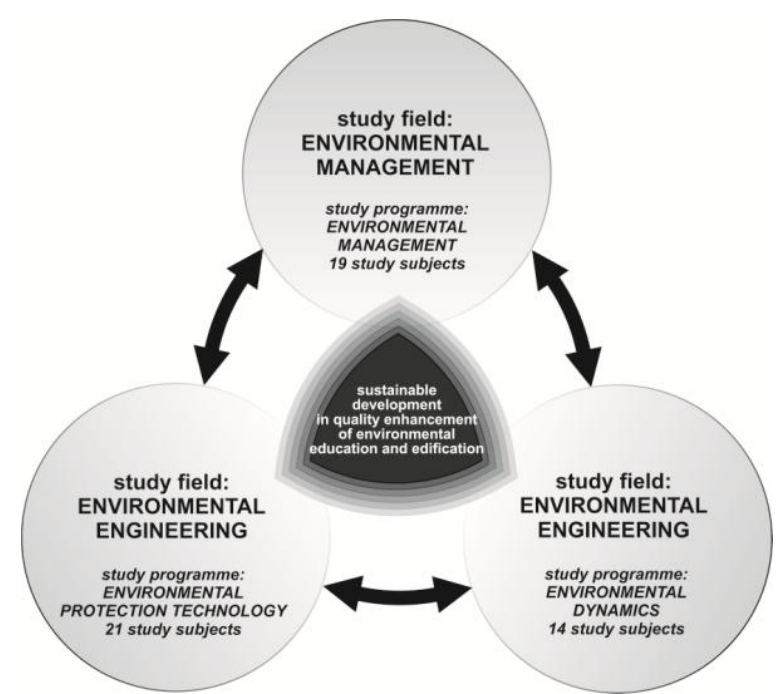

Fig. 3. Sustainable development in environmental education as integration of engineering, management and dynamics Source: own study.

By developing the new study programme it will prevent a frequent diffusion of study subjects in the frame of accredited study programmes: "Environmental Protection Technology" and "Environmental 
Management" and students will be better organized and more specifically. This way the department would educate students with more flexibility and orientation of their knowledge and skills.

In Fig. 3 there are individual subjects of Environmental Management, which are oriented in the areas:

- Activity impacts assessment of environment according to the law of No. 24/2006 Collection of Laws;

- Environmental oriented regulation and audit;

- Systems of environmental and integrated management and accreditation and certification of these systems by means of standards ISO 14001;

- Registration Eco-Management and Audit Scheme (EMAS), etc.

The study programme: Environmental Protection Technology, in the study field: Environmental Engineering deals with:

- Industrial production versus environmentalism;

- Industrial production versus consumption;

- Industrial production versus production and assembly processes.

The study programme: Environmental Dynamics, in the study field: Environmental Engineering would deal with:

- Diagnostics of environmental factors;

- Objectification of environmental factors;

- Computer Aided Simulations (Stella, Vensim).

The individual subjects will be created by means of the above-mentioned divisions. All of the programmes have got one role to keep sustainable development in mechanical engineering industry and in our society.

\section{Summary and conclusions}

At present ecologisation and sustainable development are developing trends and strategies in industries. Sustainable development is understood like very well balanced social-economic-environmental development. However, it is not separated from environmental consciousness, feeling and knowledge. It is encouraging that there is progress in environmental edification and education in Slovakia. The interest in environmental education still increases and influences the sustainable development strategy and environmental policy of the
Slovak Republic. It is important to recognise that Slovakia has got the largest environmental debts in comparison with other European states (KozovÁ M. 2007). That is why it is necessary to work towards solving this issue. Knowledge of the areas Environmental Protection and Generation must still be developed and enlarged for the benefit of future generations. It is expected that there will be new environmental study fields, programmes, forms and subjects for all school levels and for life-long education. Only qualitative environmental edification and education can be regarded as the "initiator" and "engine" for a change in people's attitudes and behaviours.

\section{Acknowledgement}

This article was prepared in the framework of project VEGA 1/0481/13 „Study of selection environmental impact of building materials."

\section{References}

1. Chovancová J., Harausová H. 2013. Education of the next generation of managers in context of green economy. Journal of economic development, environment and people. Vol.2.

2. FABIAN M. et al. 2013. The history of the introduction of Cad Systems into practice and teaching in engineering. Transport \& Logistics, Vol. 29.

3. KLINDA J. 1995. Environmentalistics and Law/ Short Dictionary of Environmental Law. Ministry of Environment Slovakia. Bratislava. (In Slovak).

4. Kopas M., Oravec M. 2005. Safe design - minimisation of loses. International Conference on ComputerAided Ergonomics and Safety. Košice.

5. KozovÁ M. 2007. Faculty of Mechanical Engineering in Kosice inspired of outland. Enviromagazin, Vol. 12 (In Slovak).

6. PALFY P. 2013. Measurement of quality in education. Quality of Production: proceedings of selected article. Košice. ISBN 978-80-553-1466-2. (In Slovak).

7. PiATRIK M., VincíKOVÁ S., HALAŠOVÁ M. 2005: New trends in education of PhD-students for environmental management systems. In Environmental management for education and edification, Vol.II; No.1. Department of ecology and environmental education, Faculty of Natural Science, University of Matej Bel in Banská Bystrica. 